\title{
Cichorin A: a benzo-isochromene from Nypa fruticans endophytic fungus Pestalotiopsis sp.
}

\author{
GIDEON O. ALADE ${ }^{1,25^{*}}$, JONES O. MOODY ${ }^{2}$, OLANREWAJU R. AWOTONA ${ }^{1}$, DAOWAN LAI ${ }^{3}$, \\ SABURI A. ADESANYA ${ }^{4}$, PETER PROKSCH ${ }^{5}$
}

${ }^{1}$ Department of Pharmacognosy \& Herbal Medicine

Niger Delta University

Wilberforce Island, Nigeria

${ }^{2}$ Department of Pharmacognosy

University of Ibadan

Ibadan, Nigeria

${ }^{3}$ Department of Plant Pathology

College of Plant Protection

China Agricultural University

Beijing 100193, China

${ }^{4}$ Department of Pharmacognosy

Obafemi Awolowo University

Ile Ife, Nigeria

${ }^{5}$ Institute für Pharmaceutical Biologie und Biotechnologie

Heinrich Heine University

Düsseldorf, Germany

"Corresponding author: phone: +2348067368038, e-mail: aladegideon@yahoo.com

\section{Summary}

Introduction: Similar bioactive metabolites are obtainable from host plants as well as the endophytic fungi residing in them.

Objective: The aim of the study is to isolate the major compound(s) from the endophytic fungus residing in Nypa fruticans Wurmb, Arecaceae family.

Methods: Purification of the ethyl acetate extract of the isolated endophytic fungus was performed by employing different chromatographic techniques and structural elucidation of the isolated compound was carried out using UV and NMR spectroscopic methods. 
Results: Cichorin A was isolated from the ethyl acetate extract of the solid rice cultures of Pestalotiopsis sp., isolated from $N$. fruticans, collected in Nigeria.

Conclusions: This compound is being isolated for the first time from a fungus; it is commonly isolated from the plant Cichorium intybus L. (Compositae).

Key words: cichorin, Pestalotiopsis, endophytic fungus, bioactive compounds, Nypa fruticans

\section{INTRODUCTION}

Research in plant endophytic fungi has increased tremendously due to the special ability to produce the same or similar compounds originated from their host plants, as well as other bioactive compounds [1]. This has helped in the sustainable production of important active principles for treatment of diseases. For instance, the producing plants of paclitaxel, podophyllotoxin, camptothecine, vinblastine, hypericin, vincristine and diosgenin were already declared as endangered species. In order to satisfy the growing demand of market and make them more widely available, the alternative resource and potential strategy have to be developed. For some years, many efficient approaches such as field cultivation, plant cell and tissue culture, chemical syntheses for paclitaxel production have been developed, and much progress has been achieved [2]. However, it is not realistic for the production of paclitaxel with these measures as the problems of time consumption and lower yield exists and not exists. Fortunately, a paclitaxel producing endophytic fungus Taxomyces andreanae was successfully discovered from the Pacific yew (Taxus brevifolia Nutt., Taxaceae) in 1993 [3]. By now, at least 19 genera of endophytic fungi have been screened to have the ability to produce paclitaxel and its analogue. It has offered an inexhaustible source of structurally and biologically novel compounds and an alternative source of metabolites functionally identical to plant produced metabolites [4].

Ethnomedicinally, the root and leaf of Nypa fruticans are used for toothache [5]; leaves, stem and roots are employed for asthma, leprosy, tuberculosis, sore throat, liver diseases, snake bite, pain and as a stimulant in Bangladesh [6-8].

\section{MATERIAL AND METHODS}

\section{Plant collection}

The leaves of Nypa fruticans Wurmb (Arecaceae family) were collected from Onne, Rivers State; a mangrove forest in Nigeria after identification. It was thereafter authenticated by Dr. A.T. Oladele of the Department of Forestry and Wildlife Management, University of Porth Harcourt, Nigeria. A voucher specimen (NDUP 140) was deposited in the herbarium of the Niger Delta University, Wilberforce Island, Nigeria.

\section{General experimental procedures}

${ }^{1} \mathrm{H}$ NMR spectra were recorded in deuterized solvents on Bruker DRX500 NMR spectrometers. HPLC analysis was carried out on a Dionex UltiMate 3000 HPLC system (Thermo scientific) coupled to a photodiode array detector (DAD3000RS). Routine detection was performed at $235,254,280$, and $340 \mathrm{~nm}$. The separation column $(125 \times 4 \mathrm{~mm}, 1 \times$ i.d. $)$ was prefilled with Eurospher-10 C18 (Knauer, Germany), and the following gradient was used $(\mathrm{MeOH} / 0.1 \%$ formic acid in water); $0 \mathrm{~min}, 10 \% \mathrm{MeOH} ; 5 \mathrm{~min}$, $10 \% \mathrm{MeOH}$; $35 \mathrm{~min}, 100 \% \mathrm{MeOH} ; 5$ min, 100\% $\mathrm{MeOH}$ with a flow rate of $1.0 \mathrm{ml} / \mathrm{min}$. The HPLC separation was performed on a semi-preparative HPLC system of Lachrom-Merck Hitachi (Pump L7100 and UV detector L7400). The separation column $(300 \times 8 \mathrm{~mm})$ was prefilled with Europhere 100-C18 (Knauer, Germany) using a flow rate of $5.0 \mathrm{ml} / \mathrm{min}$. Column chromatography was performed using Merck MN Silica gel 60 M (0.04$0.063 \mathrm{~mm}$ ) and Sephadex LH20 (GE HealthCare) as stationary phases as required. For TLC analyses pre-coated Silica Gel $60 \mathrm{~F}_{254}$ plates (Merck) were used followed by detection under UV at 254 and $366 \mathrm{~nm}$ and observation after spraying with anisaldehyde reagent. All solvents were distilled prior to use, and spectral grade solvents were used for spectroscopic measurements.

\section{Isolation and identification of fungal strain}

The fungal strain was isolated from the fresh and healthy leaf of $N$. fruticans, which was collected in Nigeria in February 2012. The leaf was rinsed twice 
in sterilized distilled water. The surface of the leaf was sterilized by immersing the leaves in $70 \%(v / v)$ ethanol for $2 \mathrm{~min}$, followed by rinsing with sterilized nano-pure water in order to remove any epiphytic fungi. The successful sterilization was confirmed by applying the leaf to a malt agar filled petri dish for $1 \mathrm{~min}$. Afterwards the leaf was cut into small segments (approximately $1 \mathrm{~cm}$ length) and applied to an antibiotic containing malt agar petri dish to avoid bacterial growth (medium composition: $15 \mathrm{~g} / \mathrm{l}$ malt extract, $15 \mathrm{~g} / \mathrm{l}$ agar, $0.1 \mathrm{~g} / \mathrm{l}$ streptomycin and $0.2 \mathrm{~g} / \mathrm{l}$ chloramphenicol in distilled water ( $\mathrm{pH}: 7.4-7.8)$. The plates were incubated for many days at room temperature $\left(21^{\circ} \mathrm{C}\right)$ until several hyphae were found growing from the plant material. These were transferred to fresh Petri dishes with the same medium, incubated again at room temperature $\left(21^{\circ} \mathrm{C}\right)$ and periodically checked for culture purity.

The fungus was identified as Pestalotiopsis sp. on the basis of a molecular biological protocol, using the amplifictation and sequencing of the ITS region as described previously [9]. A voucher strain (strain designation: LNF-L-1) was deposited in Prof. Peter Proksch laboratory at the Institute of Pharmaceutical Biology and Biotechnology, Heinrich Heine University, Düesseldorf, Germany.

\section{Cultivation of the fungus}

Scale-up fermentation of the fungus for the isolation and identification of secondary metabolites was carried out in six Erlenmeyer flasks (1 l each). To each of the flasks was added $100 \mathrm{~g}$ of commercially available rice and $110 \mathrm{ml}$ of distilled water. The flasks with the contents were thereafter autoclaved at $121^{\circ} \mathrm{C}, 2 \mathrm{bar}$ for $20 \mathrm{~min}$. A small part of the mycelium was thereafter transferred under sterile condition to the rice medium in each of the flasks. The fungus was grown on solid rice medium at room temperature under static conditions for 21 days.

\section{Extraction and fractionation}

After incubation, $400 \mathrm{ml}$ of ethylacetate (EtOAc) was added to each of the flasks and left overnight, followed by filtration. The extraction was carried out twice and the resulting EtOAc extract was taken to dryness and partitioned between $n$-hexane and 90\% $\mathrm{MeOH}$. Evaporation of the $90 \% \mathrm{MeOH}$ fraction gave $400 \mathrm{mg}$ of extract. The $90 \%$ methanolic fraction was chromatographed on silica by vacuum liquid chromatography using $n$-hexane in gradient with ethyl acetate at $10 \%$ interval to obtain 11 different fractions. Based on the TLC and UV profiles, fraction 5 (75 mg; obtained from $n$-hexane : ethyl acetate (6:4)) was further chromatographed on Sephadex LH-20 using dichloromethane: methanol (1:1) as solvent system to afford six pooled fractions based on detection by TLC (silica gel $\mathrm{F}_{254}$, Merck, Darmstadt, Germany) using EtOAc- $\mathrm{MeOH}-\mathrm{H}_{2} \mathrm{O}$ (80:15:50) as solvent system and fraction 3 (19 $\mathrm{mg}$ ) was thereafter subjected to semi-preparative HPLC (Merck, Hitachi L-7100) using a Eurosphere $100-10 \mathrm{C} 18$ column $(300 \times 8 \mathrm{~mm}$, $1 \times$ i.d.) with the following gradient $\left(\mathrm{MeOH}-\mathrm{H}_{2} \mathrm{O}\right)$ : 0 min, 10\% MeOH; 5 min, $10 \% \mathrm{MeOH} ; 35$ min 100\% $\mathrm{MeOH} ; 45 \mathrm{~min}, 100 \% \mathrm{MeOH}$ to afford a compound, the structure of which was elucidated on the basis of extensive analysis of one dimensional NMR spectroscopy.

Ethical approval: The conducted research is not related to either human or animal use.

\section{RESULTS AND DISCUSSION}

Cichorin A, $4.1 \mathrm{mg}$ (fig. 1) was isolated as white solid, UV $\lambda_{\max }(\mathrm{MeOH})$ 250.0, $255.9 \mathrm{~nm},{ }^{1} \mathrm{H}$ NMR $\left(600 \mathrm{MHZ}, \mathrm{CDCl}_{3}\right) \delta(\mathrm{ppm}) .1 .73(3 \mathrm{H}, \mathrm{s}, \mathrm{H}-13)$, 2.24 (3H, s Me-8), 3.95 (3H, s, 10-OMe), 4.30 (1H, d, $J=2.5 \mathrm{~Hz}, \mathrm{H}-3), 4.85(1 \mathrm{H}, \mathrm{s}, \mathrm{H}-12 \mathrm{a}), 4.91(1 \mathrm{H}, \mathrm{s}, \mathrm{H}-$ 12b), $5.07(3 \mathrm{H}, \mathrm{s}, \mathrm{H}-1, \mathrm{H}-4), 6.41(1 \mathrm{H}, \mathrm{d}, J=2.0 \mathrm{~Hz}$, $\mathrm{H}-9), 6.85(1 \mathrm{H}, \mathrm{d}, J=2.0 \mathrm{~Hz}, \mathrm{H}-7), 6.89(1 \mathrm{H}, \mathrm{d}, J=$ $9.0 \mathrm{~Hz}, \mathrm{H}-5), 7.64(1 \mathrm{H}, \mathrm{d}, J=9.0 \mathrm{~Hz}, \mathrm{H}-6)$.

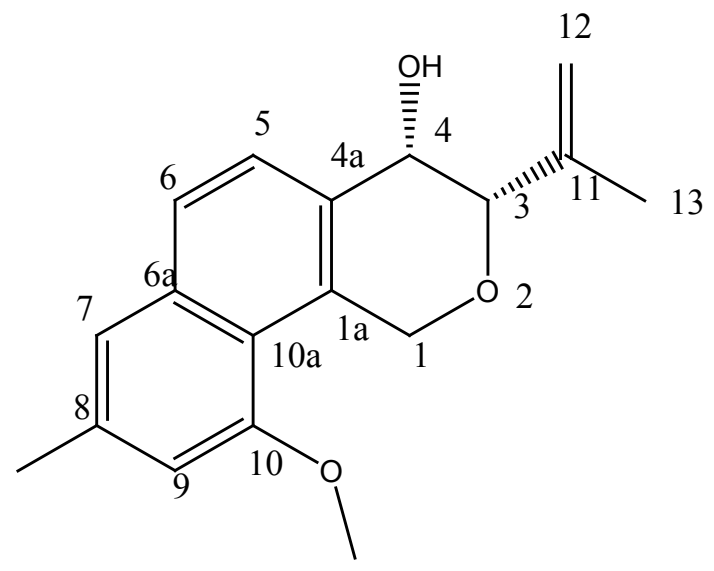

Figure 1.

Chemical structure of cichorin A

The compound was identified as cichorin A, when compared with literature [10]. ${ }^{1} \mathrm{H}$ NMR spectrum 
showed an ortho coupled aromatic proton signals at $\delta 7.64(1 \mathrm{H}, \mathrm{d}, J=9.0 \mathrm{~Hz}, \mathrm{H}-6), 6.89(1 \mathrm{H}, \mathrm{d}, J=$ $9.0 \mathrm{~Hz}, \mathrm{H}-5)$, two meta-coupled aromatic proton signals at $\delta 6.85(1 \mathrm{H}, \mathrm{d}, J=2.0 \mathrm{~Hz}, \mathrm{H}-7), 6.41(1 \mathrm{H}, \mathrm{d}, J$ $=2.0 \mathrm{~Hz}, \mathrm{H}-9)$, one methoxy singlet at $\delta 3.95(3 \mathrm{H}, \mathrm{s}$, $\mathrm{OMe})$, and one aromatic methyl singlet at $\delta 2.24(3 \mathrm{H}$, s Me-8). Two oxymethine proton signals at $\delta 5.07$, 4.30 were also shown in the ${ }^{1} \mathrm{H}$ NMR. Also present were one olefinic methyl at $\delta 1.73$ and signals for exocyclic methylene at $\delta 4.85$ and 4.91 . This structure was therefore established by comparison with the literature to be 10-methoxy-8-methyl-3-(prop1-en-2-yl)-3,4-dihydro- $1 H$-benzo[h]isochromen4-ol (fig. 1), named cichorin A. It was first isolated from the plant Cichorium intybus L. (Compositae), a medicinally important plant whose root is used as antihepatotoxic, antiulcerogenic and anti-inflammatory and also useful in the treatment of anorexia and dyspepsia [10]. This is an alternative way of obtaining this compound rather than the heavy burden of the isolation from plant sources which may not be sustainable.

\section{CONCLUSION}

Cichorin A is isolated for the first time from endophytic fungus, this is therefore an alternative way of producing it and it is a means of conservation of the plant species from which it is being isolated.

\section{ACKNOWLEDGMENT}

This study was supported by Grants of the BMBF awarded to P. P. GOA wants to thank Federal Government of Nigeria through TETFUND for travel grant.

Conflict of interest: Authors declare no conflict of interest.

\section{REFERENCES}

1. Strobel G, Daisy B, Castillo U, Harper J. Natural products from endophytic microorganisms. J Nat Prod 2004; 67:257-268. doi: http://dx.doi. org//10.1021/np030397v

2. Zhou L, Wu J. Development and application of medicinal plant tissue cultures for production of drugs and herbal medicinals in China. Nat Prod Rep 2006; 23:789-810. https://www.ncbi.nlm.nih. gov/pubmed/17003910

3. Stierle A, Strobel G, Stierle D. Taxol and taxane production by Taxomyces andreanae, an endophytic fungus of Pacific yew. Science 1993; 260:214-216. https://www.ncbi.nlm.nih.gov/ pubmed/8097061

4. Strobel GA, Hess WM, Ford E, Sidhu RS, Yang $\mathrm{X}$. Taxol from fungal endophytes and issue of biodiversity. J Ind Microbiol 1996; 96(17):417423. https://link.springer.com/article/10.1007/ BF01574772

5. Ganesan S. Traditional oral care medicinal plants survey of Tamil Nadu. Nat Prod Rad 2008; 7(2):166-172. http://nopr.niscair.res.in/handle/ $123456789 / 5662$

6. Mollik AH, Hossan S, Paul AK, Rahman TU, Jahan R, Rahmatullah M.A comparative analysis of medicinal plants used by folk medicinal healers in three districts of Bangladesh and inquiry as to mode of selection of medicinal plants. ERA 2010; 8:195-218. doi: http://dx.doi.org/10.17348/ era.8.0.195-218

7. Rahmatullah M, Sadeak SMI, Bachar SC et al. Brine shrimp toxicity study of different Bangladeshi medicinal plants. Adv Nat Appl Sci 2010; 4:163-173.

8. Prasad N, Yang B, Kong KW, Khoo HE, Sun J, Azlan A et al. Phytochemicals and antioxidant capacity of Nypa fruticans Wurmb. fruit. Evid Based Compliment Altern Med 2013:154606. doi: http://dx.doi.org/10.1155/2013/154.606

9. Kjer J, Debbab A, Aly AH, Proksch P. Methods for isolation of marine-derived endophytic fungi and their bioactive secondary products. Nat Protoc 2010; 5:479-490. http://www.tandfonline. com/doi/abs/10.1080/10286020.2011.573789

10. Hussain H, Hussain J, Saleem M, Miana GA, Riaz M, Krohn K, et al. Cichorin A: a new benzo-isochromene from Cichorium intybus. J Asian Nat Prod Res 2011; 13(6):566-569. 


\title{
Cychoryna A: benzo-izochromen z Pestalotiopsis sp. - endofitycznego grzyba Nypa fruticans
}

\author{
GIDEON O. ALADE ${ }^{1,25^{*}}$, JONES O. MOODY ${ }^{2}$, OLANREWAJU R. AWOTONA ${ }^{1}$, DAOWAN LAI ${ }^{3}$ \\ ,SABURI A. ADESANYA ${ }^{4}$, PETER PROKSCH ${ }^{5}$
}

${ }^{1}$ Department of Pharmacognosy \& Herbal Medicine
Niger Delta University
Wilberforce Island, Nigeria
${ }^{2}$ Department of Pharmacognosy
University of Ibadan
Ibadan, Nigeria
${ }^{3}$ Department of Plant Pathology
College of Plant Protection
China Agricultural University
Beijing 100193, China
${ }^{4}$ Department of Pharmacognosy
Obafemi Awolowo University
Ile Ife, Nigeria
${ }^{5}$ Institute für Pharmaceutical Biologie und Biotechnologie
Heinrich Heine University
Düsseldorf, Germany
*autor, do którego należy kierować korespondencję: tel.: +2348067368038 , e-mail: aladegideon@yahoo.com

\section{Streszczenie}

Wstęp: Z roślin - gospodarzy oraz z ich endofitycznych grzybów można otrzymać podobne aktywne metabolity.

Cel: Celem prowadzonych badań było wyizolowanie głównego związku/związków z endofitów grzybowych zasiedlających nipę krzewinkową (palmę krzaczastą) Nypa fruticans Wurmb (Arecaceae).

Metody: Oczyszczenie ekstraktu z izolowanych endofitów grzybowych, otrzymanego za pomocą octanu etylu, przeprowadzono za pomocą różnych technik chromatograficznych . Wyjaśnienie struktury wyizolowanego związku przeprowadzono metodą spektoskopii NMR.

Wyniki: Z ekstraktu (otrzymanego za pomocą octanu etylu) z kultur Pestalotiopsis sp. (izolowanych z $N$. fruticans z Nigerii), hodowanych na pożywkach stałych ryżowych, otrzymano cychorynę A.

Wnioski: Związek ten, powszechnie izolowany z rośliny Cichorium intybus L. (Compositae), po raz pierwszy został wyizolowany z grzybów.

Słowa kluczowe: cychoryna, Pestalotiopsis, grzyby endofityczne, związki czynne, Nypa fruticans 